\title{
Synthesis of tricyanovinyl-substituted thienylpyrroles and characterization of the solvatochromic, electrochemical and non-linear optical properties
}

\author{
M. Manuela M. Raposo, ${ }^{a *}$ Ana M. R. C. Sousa, ${ }^{a}$ G. Kirsch, ${ }^{b}$ F. Ferreira, ${ }^{\mathrm{c}}$ M. Belsley, ${ }^{\mathrm{c}}$ \\ E. de Matos Gomes ${ }^{\mathrm{c}}$ and A. Maurício C. Fonseca ${ }^{\mathrm{a}}$
}

\begin{abstract}
a Centro de Química, Universidade do Minho, Campus de Gualtar 4710-057 Braga, Portugal

b Laboratoire d'Ingénierie Moléculaire et Biochimie Pharmacologique, UFR SciFA, Université de Metz, 1, Boulevard Arago, Metz Technopôle, 57078 Metz Cedex 3, France

c Departamento de Física, Universidade do Minho, Campus de Gualtar 4710-057 Braga, Portugal
\end{abstract}

\begin{abstract}
Tricyanovinyl-substituted 1-(alkyl)aryl-2-(2'-thienyl)pyrroles 1 have been synthesized by direct tricyanovinylation reaction of 1-(alkyl)aryl-2-(2'-thienyl)pyrroles 2 using TCNE. The tricyanovinyl- derivatives $\mathbf{1}$ display dramatic reductions in both their optical and electrochemical band gaps relative to thienylpyrrole precursors 2 . The solvatochromic behavior of compounds $\mathbf{1}$ was investigated in a variety of solvents. Hyper-Rayleigh scattering was used to measure the first hyperpolarizabilities $\beta$ of the mentioned compounds. The $\beta$ values show that the new compounds prepared could be used on the manufacture of materials with good non-linear (NLO) properties.
\end{abstract}

Keywords: tricyanovinylation, donor-acceptor thienylpyrroles, chromophores, solvatochromism, electrochemistry, Hyper-Rayleigh scattering (HRS), non-linear optical (NLO) material.

\section{Introduction}

Novel conjugated organic molecules containing both donor and acceptor moieties have attracted much attention because they are critical components for many great advanced technologies such as non-linear optical (NLO), photo- and electroluminescent devices,

*Corresponding author. Phone: +351 253 604381: Fax: +351 253 678983: e-mail: mfox@quimica.uminho.pt 
and photovoltaic devices. Organic NLO materials have many advantages over inorganic materials, such as large nonlinear optical coefficients, greater ease for synthetic design, simple preparation and lower cost. ${ }^{1-3}$ It has been revealed that the second order hyperpolarizabilities $(\beta)$ of heterocyclic chromophores are often higher than their benzene analogues. ${ }^{4-12}$ Recently we have also demonstrated that donor-acceptor substituted bithiophenes and terthiophenes have many favorable features as NLO materials. ${ }^{13-16}$ Conjugated thiophene and pyrrole derivatives as donors combined with substituted acceptor groups are promising candidates among such D-A systems due to their numerous applications. Unlike the thiophene or furane analogues, the pyrrole ring can be further substituted on the nitrogen atom so that the electron density of the chromophore can be changed. In addition, replacing the N-H group of the pyrrole ring with another substituent would eliminate some intramolecular hydrogen bond which might also affect their macroscopic structures and NLO properties. Some of these molecules, in particular the thienylpyrroles, have served as prospective monomers for non-linear optical materials and organic conductive polymers. The latter combine high electrical conductivity, with thermal and environmental stability. ${ }^{17-29}$ In the last few years donor substituted tricyanovinyl compounds have received a lot of interest. Due to their strong solvatochromic properties, which mainly originate from their donoracceptor substitution, they can be used as model compounds for dyes with strong NLO properties. Such dyes have found applications in manufacturing new materials capable of generating special electrooptical effects, such as frequency doubling or wave mixing. ${ }^{20-24,30}$ Therefore, tricyanovinyl- derivatives 1 represent promising candidates for NLO and other applications. As part of our continuing interest in non-linear optical material ${ }^{13-16,31-32}$ we have synthesized new tricyanovinyl-substituted thienylpyrroles $\mathbf{1}$, by tricyanovinylation reaction of thienylpyrroles 2 described by us recently. ${ }^{33}$

\section{Results and discussion}




\subsection{Synthesis}

Recently we have developed a method for the synthesis of 1-alkyl(aryl)-2-(2'thienyl)pyrroles 2.33 These compounds have proved to be versatile substrates in tricyanovinylation reactions, allowing us to prepare several new donor-acceptor substituted thienylpyrroles.

Electrophilic substitution reactions of thienylpyrroles were found to be very selective. According to earlier reports, the pyrrole nitrogen atom has a greater ability to delocalize the positive charge of $\sigma$-complexes than the sulfur atom in thiophene; pyrrole is therefore considerably more reactive towards electrophilic substitution than thiophene. Even when both $\alpha$-positions of the pyrrole ring are occupied, electrophilic substitution will preferentially occur in the $\beta$-position of the pyrrole ring rather than the $\alpha$-position of the thiophene ring. ${ }^{34-38}$ The reactivity of these systems has been demonstrated with the use of electrophilic reactions producing derivatives with the electrophile substituted primarily on the pyrrole ring. ${ }^{37-44}$

Accordingly, tricyanovinylation of thienylpyrroles $\mathbf{2}$ proceeded selectively in the pyrrole ring to form the corresponding tricyanovinyl-substituted thienylpyrroles $\mathbf{1}$. The synthesis of tricyanovinyl derivatives 1a-i is outlined in Scheme 1. The tricyanovinylgroup was introduced in a manner similar to that of previously reported procedure. ${ }^{13}$ Tricyanovinylation was carried out in DMF within $15 \mathrm{~min} .-3 \mathrm{~h}$ at $\mathrm{rt}$. Under these conditions 1-aryl-2-(2'-thienyl)pyrroles $\mathbf{2 b}$-i reacted regioselectively forming 1-aryl-2(2'-thienyl)-5-tricyanovinylpyrroles $\mathbf{1 b}$-i in 31-73\% yield (Table 1). 1-n-Propyl-2-(2'thienyl)pyrrole 1a behaves quite differently in this reaction (Scheme 1): the main reaction product was $\mathbf{1} \mathbf{a}_{2}(29 \%)$ and results from the substitution at the 3-position of the pyrrole ring; in addition, the 5- and 4-tricyanovinyl-substituted pyrrole derivatives $\mathbf{1} \mathbf{a}_{1}$ $(12 \%)$ and $1 \mathbf{a}_{3}(8 \%)$ were also isolated (Table 1, entries 1-3). In interpreting these results it seems appropriate to take into account the possible steric influence of the $n$ propyl group impeding the substitution at the $\alpha$-position of the pyrrole ring. ${ }^{36}$ 
The structures of tricyanovinyl-substituted pyrrole derivatives 1 were unambiguously confirmed by their analytical and spectral data. In the ${ }^{1} \mathrm{H}$ NMR spectrum of 5 tricyanovinyl-substituted pyrrole derivative $\mathbf{1 a}_{1}$ two signals at about 6.82 and $7.62 \mathrm{ppm}$ were detected. Both signals appear as doublets with coupling constants of $4.5 \mathrm{~Hz}$ indicating the presence of two adjacent protons $(3-\mathrm{H}$ and $4-\mathrm{H})$ at the corresponding pyrrole moiety. In the ${ }^{1} \mathrm{H}$ NMR spectrum of 3-tricyanovinyl-substituted pyrrole derivative $1 \mathbf{a}_{2}$ two signals at about 7.18 and $7.34 \mathrm{ppm}$ were detected. Both signals appear as doublets with coupling constants of $3.3 \mathrm{~Hz}$. These signals were attributed to the $5-\mathrm{H}$ and $4-\mathrm{H}$ in the pyrrole moiety. In the ${ }^{1} \mathrm{H}$ NMR spectrum of 4-tricyanovinylsubstituted pyrrole derivative $\mathbf{1 a}_{3}$ two signals at about 7.15 and 8.13 ppm were detected. Both signals appear as doublets with coupling constants of $2.1 \mathrm{~Hz}$. These signals were attributed to the $3-\mathrm{H}$ and $5-\mathrm{H}$ in the pyrrole moiety. In all the ${ }^{1} \mathrm{H}$ NMR spectra of tricyanovinyl-substituted pyrrole derivatives 1a-i three signals at about 7.08-7.35 (multiplet), 7.30-7.58 (double doublet) and 7.45-7.92 (double doublet) were detected. These signals were attributed respectively, to the 4', 3' and 5' -H protons in the thiophene moiety.

The tricyanovinyl derivatives synthesized are colored with metallic luster. As for similar compounds, the color of the tricyanovinyl-substituted pyrroles $\mathbf{1}$ depend on the substituent on the nitrogen of the pyrrole ring. ${ }^{21-25}$

\section{<Scheme 1> \\ $<$ Table 1>}

\subsection{UV-visible study of tricyanovinyl-substituted thienylpyrroles}

All the tricyanovinyl-substituted thienylpyrroles 1 synthesized are deeply colored compounds which exhibit intense absorptions in the UV-visible range. The position of these absorptions is influenced by the structure of the compounds, for example by the 
substituent on the nitrogen atom of the pyrrole ring and by the position of substitution of the tricyanovinyl group on the pyrrole ring.

The electronic spectra of tricyanovinyl- thienylpyrrole derivatives $\mathbf{1}$ were recorded in ethanol (Table 1). Dramatic differences in energy occur upon tricyanovinylsubstitution of thienylpyrroles $\mathbf{1}$. For example, thienylpyrrole $\mathbf{2 e}\left(\lambda_{\max }=286.5 \mathrm{~nm}\right)$ is shifted $239 \mathrm{~nm}$ upon tricyanovinyl substitution (tricyanovinyl- derivative $1 \mathbf{e}, \lambda_{\max }=$ $525.5 \mathrm{~nm}$ ) (Figure 1, Table 1, entry 7). These effects have been attributed to the stabilization of LUMO by the electron-withdrawing groups. ${ }^{45}$ The influence of the substituent on the nitrogen atom of the pyrrole ring is demonstrated by comparison of the absorption maxima of compounds $\mathbf{1} \mathbf{a}_{\mathbf{1}}$ and $\mathbf{1 e}$ as the longest wavelength transition is shifted from $491.5 \mathrm{~nm}$ in 1-(n-propyl)-2-(2'-thienyl)-5-tricyanovinylpyrrole 1a $\mathbf{1}_{1}$ (Table 1 , entry 1) to $525.5 \mathrm{~nm}$ for $1-\left(2^{\prime \prime}, 4^{\prime \prime}\right.$-dimethoxyphenyl)-2-(2'-thienyl)-5tricyanovinylpyrrole 1e (Table 1, entry 7). The influence of the position of the tricyanovinyl group on the pyrrole ring on $\lambda_{\max }$ of absorption for tricyanovinyl derivatives $\mathbf{1} \mathbf{a}_{\mathbf{1}}-\mathbf{- 1 \mathbf { a } _ { 3 }}$ is noteworthy. The difference in $\lambda_{\max }$ values $\left(\Delta \lambda_{\max }\right)$ between the three compounds $\left(\mathbf{1} \mathbf{a}_{\mathbf{1}}-\mathbf{- 1 \mathbf { a } _ { 3 }}\right)$ is in the range of 75-83 nm (Table 1, entries 1-3). As expected, the introduction of the tricyanovinyl group in the 5-position of the pyrrole ring $\left(\mathbf{1}_{\mathbf{1}}\right)$, relative to the same acceptor group in the 3-position $\left(\mathbf{1} \mathbf{a}_{\mathbf{2}}\right)$, results in a bathochromic shift in the $\lambda_{\max }$ of absorption for $\mathbf{1} \mathbf{a}_{\mathbf{1}}$ due to more extensive electron delocalization.

It is widely recognized that low energy bands in the UV-vis. spectra ${ }^{46}$ and large solvatochromism ${ }^{7,47-48}$ are good indicators of potential NLO properties.

\section{$<$ Figure 1 >}

\subsection{Solvatochromic behavior of tricyanovinyl-substituted thienylpyrroles}

To evaluate the intermolecular forces between the solvents and the solute molecules and in order to determine the best indicator dye, we carried out a preliminary study of the absorption spectra for compounds $\mathbf{1}$ in solvents of different solvatation character (cyclohexane, ethyl acetate and DMF). The highest energy transitions are found with non-polar solvents (cyclohexane). More polar solvents such as DMF resulted in lower 
energy transitions. This behavior has been defined as a positive solvatochromic response $\left(\Delta v=649 \mathrm{~cm}^{-1}\right.$ for $\mathbf{1 b}$ and $\Delta v=1260 \mathrm{~cm}^{-1}$ for $\left.\mathbf{1 a}_{\mathbf{2}}\right)$ that is related to a greater stabilization of the excited state relative to the ground state with increasing polarity of the solvent. We found that compounds $\mathbf{1 a}_{1}\left(\Delta v=1228 \mathrm{~cm}^{-1}\right), \mathbf{1}_{\mathbf{2}}\left(\Delta v=1260 \mathrm{~cm}^{-1}\right)$ and $\operatorname{1g}\left(\Delta v=804 \mathrm{~cm}^{-1}\right)$ showed the longest shifts in wavenumber maxima so a full solvatochromic study involving 14 solvents was carried out (Table 2).

The maxima of the wavenumbers for $\mathbf{1 \mathbf { a } _ { 1 }}, \mathbf{1 \mathbf { a } _ { 2 }}$ and $\mathbf{1 g}$ measured in 14 solvents as well the corresponding wavelength $\lambda$ are listed in Table 2 and compared to the $\pi^{*}$ determined by Kamlet and Taft. ${ }^{49-50}$

In view of the pronounced solvatochromism, the good correlation with $\pi^{*}$ values for the 14 solvents investigated and the long wavelength absorption in the visible range, $\mathbf{1} \mathbf{a}_{1}$, $\mathbf{1 \mathbf { a } _ { 2 }}$ and $\mathbf{1 g}$ seemed to be a very appropriate solvent polarity indicating dyes (Table 2).

\section{<Table 2>}

\subsection{Electrochemical study of tricyanovinyl-substituted thienylpyrroles}

The redox properties of tricyanovinyl-substituted thienylpyrroles 1 were investigated by cyclic voltammetry (Table 3). All compounds displayed one oxidative process under the experimental conditions. The precursors thienylpyrroles 2 showed an irreversible oxidation. Upon tricyanovinyl-substitution, the compounds display oxidation at more positive potentials as a consequence of the destabilizing effect of the electronwithdrawing tricyanovinyl group. ${ }^{51}$ For example, the 1-phenyl-2-(2'-thienyl)pyrrole $\mathbf{2 b}$ display an oxidation at $\mathrm{E}_{\mathrm{pa}}=0.53 \mathrm{~V}$ and the correspondent tricyanovinyl derivative $\mathbf{1 b}$ display an oxidation at $\mathrm{E}_{\mathrm{pa}}=0.95 \mathrm{~V}$, corresponding to the formation of the cation radical. The tricyanovinyl-substituted thienylpyrroles display two reduction processes (Table 3, Figure 2). For all compounds, the first process is stable on the cyclic voltammetry scale. A cathodic shift of reduction peak potentials was observed for 1aryl-thienylpyrroles $\mathbf{1 b}$-i relative to 1-propyl-thienylpyrrole $\mathbf{1} \mathbf{a}_{\mathbf{1}}$. For example 1- $n$ propyl-2-(2'-thienyl)pyrrole $\mathbf{1 a _ { 1 }}$ displays a reversible reduction $\mathrm{E}_{1 / 2}=0.92 \mathrm{~V}$ and 1(2"',4"-dimethoxyphenyl)-2-(2'-thienyl)-5-tricyanovinylpyrrole $\mathbf{1 e}$ displays a 
reversible reduction at $\mathrm{E}_{\mathrm{pa}}=1.05 \mathrm{~V}$. The results show that oxidative and redutive peak potentials are influenced by the substituents on the nitrogen of the pyrrole ring.

Electrochemical band gaps, (Table 3), were calculated as described previously 52 from the potentials of the anodic and cathodic processes and agree well with the calculated optical band gaps. To our knowledge, these are among the lowest band-gap materials based on thienylpyrrole derivatives.

\section{$<$ Table $3>$}

\section{$<$ Figure $2>$}

\subsection{Non-linear optical study of tricyanovinyl-substituted thienylpyrroles}

We have used the Hyper-Rayleigh scattering (HRS) method 53 to measure the first hyperpolarizability $\beta$ of the tricyanovinyl derivatives 1 using the $1064 \mathrm{~nm}$ fundamental wavelength of a laser bean. Dioxane was used as a solvent, and the $\beta$ values were measured against a reference solution of $p$-nitroaniline (PNA) ${ }^{54}$ in the same solvent. Table 4 shows the measured values of $\beta$ together with the lowest energy absorption maximum of each compound. We have used the two-level model to calculate the static second-order hyperpolarizability $\beta_{0} 55-57$ the results being included in Table 4 . The $\beta_{0}$ values are calculated using a very simple two-level model and are only indicative. The static hyperpolarisability $\left(\beta_{0}\right)$ values should, therefore, be treated with caution.

The $\beta$ values of compounds $\mathbf{1 b}-\mathbf{c}, \mathbf{1 f}-\mathbf{g}$ are virtually identical and 13-14 times of that of PNA, suggesting that, the donating properties of these aryl-thienylpyrrole moieties are comparable. However, derivatives 1d-e (having one or two methoxy- groups at ortho or ortho-para position on the aromatic ring) and compounds $\mathbf{1 h}$ and $\mathbf{1 i}$ (having one halogen, $\mathrm{F}$ or $\mathrm{Br}$, at para position on the aromatic ring) show higher $\beta$ values. The $\beta$ values are 15-17 times that of PNA, whereas the $\beta_{0}$ values are 2-3 times of PNA. Compound $\mathbf{1 a}_{2}$, having a propyl group at the 1-position of the pyrrole ring and the tricyanovinyl acceptor group at 3-position exhibit the large $\beta$ and $\beta_{0}$ values. The $\beta$ value of $\mathbf{1 a}_{\mathbf{2}}$ is 19 times that of PNA and 13 times of $\beta_{0}$.

Comparison of the $\beta$ values for $\mathbf{1} \mathbf{a}_{\mathbf{1}}-\mathbf{- 1 \mathbf { a } _ { 3 }}$ shows that the substitution of the tricyanovinylgroup at the 3-position on the pyrrole ring leads to a larger nonlinearity than the same acceptor group at $4-\left(\mathbf{1 a}_{3}\right)$ or at 5-position $\left(\mathbf{1 a}_{\mathbf{1}}\right)$. 


\section{$<$ Table 4>}

Donor-acceptor thienylpyrrole derivatives $\mathbf{1}$ were completely characterized by elemental analysis and/or HRMS, ${ }^{1} \mathrm{H}$ and ${ }^{13} \mathrm{C}$ spectroscopy, UV-visible, IR spectroscopy and cyclic voltammetry (Tables 1-3).

\section{Conclusions}

In summary, we have synthesized new tricyanovinyl- substituted thienylpyrroles $\mathbf{1}$ by direct tricyanovinylation reaction of thienylpyrroles 2 with TCNE. These compounds exhibit dramatic changes in both their electronic and redox properties in relation to the precursor materials.

The solvatochromic behavior of compounds $\mathbf{1}$ was determinated by regression analyses of absorption maxima in 14 solvents. Due to their pronounced solvatochromic properties tricyanovinyl-substituted thienylpyrroles and especially compounds $\mathbf{1} \mathbf{a}_{\mathbf{1}}, \mathbf{1 a}_{\mathbf{2}}$ and $\mathbf{1 g}$ are suitable to investigate the solvent polarity by means of their absorption wavenumbers.

Hyper-Rayleigh scattering was used to determine the first hyperpolarisability, $\beta$, the data showing that $\beta$ is dependent on the substituent on the pyrrole ring (alkyl or aryl) and on the position of substitution (3,4 or 5) of the acceptor group on the pyrrole ring. It also show that the compounds have high molecular nonlinearities as their values are 10-20 times higher that the well none PNA molecule.

In agreement with the solvatochromic, electrochemical and non-linear optical studies the new compounds prepared could be used on the manufacture of semi-conductor materials or materials with strong non-linear (NLO) properties. 


\section{Experimental}

\subsection{General}

${ }^{1} \mathrm{H}$ NMR spectra were obtained on a Varian Unity Plus Spectrometer at $300 \mathrm{MHz}$ and ${ }^{13} \mathrm{C}$ NMR spectra were determinated on a Varian Unity Plus Spectrometer at $75.4 \mathrm{MHz}$ using the solvent peak as internal reference. The solvents are indicated in parenthesis before the chemical shift values ( $\delta$ relative to TMS). Mps were determined on a Gallenkamp apparatus and are uncorrected. Infrared spectra were recorded on a Perkin Elmer 1600 FTIR spectrophotometer. EI mass spectra EI (70 eV) and HRMS were run on a Unicam GC-MS 120. Elemental analysis was carried out on a Leco CHNS-932. Voltammetric measurements were performed using a potentiostat/galvanostat AUTOLAB /PSTAT 12 with a low current module ECD from ECO-CHEMIE and the data analysis was processed by the General Purpose Electrochemical System software package also from ECO-CHEMIE. Three electrode, two-compartment cells equipped with vitreous carbon-disc working electrodes, a platinum-wire secondary electrode and a silver-wire pseudo-reference electrode were employed for cyclic voltammetric measurements. The concentrations of the compounds were typically $1-2 \mathrm{mmol} \mathrm{dm}^{-3}$ and $0.1 \mathrm{~mol} \mathrm{dm}{ }^{-3}\left[\mathrm{NBu}_{4}\right]\left[\mathrm{BF}_{4}\right]$ was used as the supporting electrolyte in acetonitrile solvent. The potential was measured with respect to ferrocinium-ferrocene as an internal standard. Column chromatography was performed on Merck silica gel 60 (Art 9385). Light petroleum refers to solvent boiling in the range $40-60{ }^{\circ} \mathrm{C}$.

The experimental set-up for hyper-Rayleigh measurements is very similar to the one presented by Clays et al. ${ }^{53}$ The incident beam came from a Q-switched Nd:YAG laser $(10 \mathrm{~Hz}, \sim 20 \mathrm{~mJ}, \sim 10 \mathrm{~ns})$ at a fundamental wavelength of $1064 \mathrm{~nm}$ and was focused in the solution (beam diameter $\sim 0.5 \mathrm{~mm}$ ). The Hyper-Rayleigh signal was normalized by a second harmonic signal from a quartz plate to compensate for laser power fluctuations. The concentrations of the solutions under study were chosen so that the corresponding relative Hyper-Rayleigh signals fall within the dynamic range of the apparatus. All solutions were previously filtered $(0.2 \mu \mathrm{m}$ porosity) to avoid spurious signals from suspended impurities. The first hyperpolarizabilities $\beta$ of the molecules in dioxane solutions were measured using the external reference method. ${ }^{54}$ For two dilute solutions of cromophores with dominant hyperpolarizabilities along the charge transfer axis, in 
the same solvent, the relative hyperpolarizability is given by $\beta / \beta_{\text {ref }}=m / m$ ref where $m$ is the coefficient of variation of HRS signal with cromophore concentration. The reference chosen was a solution of PNA $1 \times 10^{-2} \mathrm{M}$, in dioxane since its $\beta$ is known from EFISH measurements for the same wavelength. ${ }^{58-59}$ For each solution, we estimated the linear coefficients $m$ using two experimental points: HRS signal for the solvent and HRS signal for the solution. From the calibration value $\beta_{\mathrm{pNA} / \mathrm{p} \text {-dioxane }}=16.9 \pm 0.410^{-30}$ esu, the determined $\beta$ values of the present compounds. The error associated with the HRS measured $\beta$ values is $10 \%$.

The synthesis of thienylpyrroles 1 has been described elsewhere. ${ }^{33}$

\subsubsection{General procedure for the synthesis of tricyanovinyl-thienylpyrroles 1 from thienylpyrroles 2 by tricyanovinylation with tetracyanoethylene (TCNE).}

A solution of thienylpyrroles $2(0.1 \mathrm{~g}, 0.40 \mathrm{mmol})$ in DMF $(1 \mathrm{ml})$ was cooled at $0{ }^{\circ} \mathrm{C}$ and then TCNE $(0.40 \mathrm{mmol})$ was added slowly. The reaction mixture was stirred during different reaction times (15min.- $3 \mathrm{~h}$ ) at room temperature. After this time the mixture was poured into ice/water. The organic layer was diluted in chloroform, washed with water and dried with anhydrous $\mathrm{MgSO}_{4}$. Evaporation of the organic extract under reduced pressure gave the crude tricyanovinyl-pyrroles $\mathbf{1}$ which were purified by "flash" chromatography on silica with increasing amounts of ether in light petroleum as eluent to give the pure products.

Tricyanovinylation of $\mathbf{1}$ a gave a mixture of 1-propyl-2-(2'-thienyl)-5tricyanovinylpyrrole 1a 1 , 1-propyl-2-(2'-thienyl)-3-tricyanovinylpyrrole $\mathbf{1 a}_{2}$ and 1propyl-2-(2'-thienyl)-4-tricyanovinylpyrrole $\mathbf{1 a}_{3}$. The first component eluted was 1 propyl-2-(2'-thienyl)-5-tricyanovinylpyrrole $\mathbf{1 a}_{1}$ as a dark red solid with metallic luster (12\%). Mp: $146.5-146.8{ }^{\circ} \mathrm{C}$. UV (EtOH): $\lambda_{\max } \mathrm{nm}\left(\varepsilon / \mathrm{M}^{-1} \mathrm{~cm}^{-1}\right) 491.5$ (16640), 368.5 (6640), 274.5 (8130). IR (Nujol) v 2215 (CN), 1500, 1458, 1432, 1325, 1163, 1141, 1094, 850, 790, $705 \mathrm{~cm}^{-1}$. ${ }^{1} \mathrm{H}$ NMR (Acetone-d 6$) \delta 0.83(\mathrm{t}, 3 \mathrm{H}, J=7.2 \mathrm{~Hz}$, $\left.\mathrm{NCH}_{2} \mathrm{CH}_{2} \mathrm{CH}_{3}\right), 1.70-1.90\left(\mathrm{~m}, 2 \mathrm{H}, \mathrm{NCH}_{2} \mathrm{CH}_{2} \mathrm{CH}_{3}\right), 4.58(\mathrm{t}, 2 \mathrm{H}, J=7.8 \mathrm{~Hz}$, 
$\mathrm{NCH}_{2} \mathrm{CH}_{2} \mathrm{CH}_{3}$ ), 6.82 (d, 1H, J=4.5 Hz, 3-H), 7.31-7.35 (m, 1H, 4'-H), 7.58 (dd, 1H, $J=3.4$ and $\left.1.2 \mathrm{~Hz}, 3^{\prime}-\mathrm{H}\right), 7.62(\mathrm{~d}, 1 \mathrm{H}, J=4.5 \mathrm{~Hz}, 4-\mathrm{H}), 7.84(\mathrm{dd}, 1 \mathrm{H}, J=5.4$ and $1.2 \mathrm{~Hz}$, $\left.5^{\prime}-\mathrm{H}\right) .{ }^{13} \mathrm{C} \mathrm{NMR}\left(\mathrm{CDCl}_{3}\right) \delta 10.52,25.06,48.09,112.90,113.14,113.49,115.80$, 124.07, 126.15, 126.30, 128.33, 129.26, 129.31, 130.99, 142.29. MS (EI) $\mathrm{m} / z$ (\%): 292 $\left(\mathrm{M}^{+}, 52\right), 250$ (33), 249 (100), 224 (8), 205 (6), 163 (6). HRMS: m/z (EI) for $\mathrm{C}_{16} \mathrm{H}_{12} \mathrm{~N}_{4} \mathrm{~S}$; calcd 292.0783; found: 292.0773. Anal. Calcd for $\mathrm{C}_{16} \mathrm{H}_{12} \mathrm{~N}_{4} \mathrm{~S}: \mathrm{C}, 65.74$; H, 4.11; N, 19.17; S, 10.97. Found: C, 65.46; H, 4.37; N, 18.71; S, 11.17. The second component eluted was 1-propyl-2-(2'-thienyl)-4-tricyanovinylpyrrole $\mathbf{1} \mathbf{a}_{3}$ as a dark orange solid (8\%). Mp: 121.3-122.4 ${ }^{\circ} \mathrm{C}$. UV (EtOH): $\lambda_{\max } \mathrm{nm}\left(\varepsilon / \mathrm{M}^{-1} \mathrm{~cm}^{-1}\right) 416.0$ (10201), 355.5 (15154), 268.5 (10437), 240.0 (12046). IR (Nujol) v 2221 (CN), 1546, 1467, 1413, 1334, 1268, 1047, 984, 955, 845, 796, 726, 693, 666, 551 cm-1. ${ }^{1} \mathrm{H}$ NMR (Acetone- $\left.\mathrm{d}_{6}\right) \delta 0.87\left(\mathrm{t}, 3 \mathrm{H}, J=7.2 \mathrm{~Hz}, \mathrm{NCH}_{2} \mathrm{CH}_{2} \mathrm{CH}_{3}\right), 1.82\left(\mathrm{~m}, 2 \mathrm{H}, \mathrm{NCH}_{2} \mathrm{CH}_{2} \mathrm{CH}_{3}\right)$, 4.30 (t, $\left.2 \mathrm{H}, J=7.8 \mathrm{~Hz}, \mathrm{NCH}_{2} \mathrm{CH}_{2} \mathrm{CH}_{3}\right), 7.15$ (d, $\left.1 \mathrm{H}, J=2.1 \mathrm{~Hz}, 3-\mathrm{H}\right), 7.22-7.26(\mathrm{~m}, 1 \mathrm{H}$, 4'-H), 7.39 (dd, $1 \mathrm{H}, J=3.6$ and $\left.1.2 \mathrm{~Hz}, 3^{\prime}-\mathrm{H}\right), 7.70$ (dd, $1 \mathrm{H}, J=5.4$ and $\left.1.2 \mathrm{~Hz}, 5^{\prime}-\mathrm{H}\right)$, 8.13 (d, 1H, J=2.1 Hz, 5-H). MS (EI) m/z (\%): 292 (M+, 98), 281 (17), 263 (15), 251 (10), 250 (100), 249 (14), 236 (5), 223 (9), 209 (6), 208 (12), 207 (94), 205 (7), 191 (6), 162 (5), 96 (8). HRMS: $m / z$ (EI) for $\mathrm{C}_{16} \mathrm{H}_{12} \mathrm{~N}_{4} \mathrm{~S}$; calcd 292.0783; found: 292.0793. The third component eluted was 1-propyl-2-(2'-thienyl)-3-tricyanovinylpyrrole $\mathbf{1 a}_{2}$ as a dark yellow solid (29\%). Mp: 118.9-119.1 ${ }^{\circ} \mathrm{C}$. UV (EtOH): $\lambda_{\max } \mathrm{nm}\left(\varepsilon / \mathrm{M}^{-1} \mathrm{~cm}^{-1}\right) 408.5$ (12360), 370.0 (13090), 260.0 (9000). IR (Nujol) v 2217 (CN), 1562, 1513, 1300, 1270, 1221, 1178, 1112, 945, 846, 762, 719, $534 \mathrm{~cm}^{-1} .{ }^{1} \mathrm{H}$ NMR (Acetone-d 6 ) $0.88(\mathrm{t}, 3 \mathrm{H}$, $J=7.5 \mathrm{~Hz}, \mathrm{NCH}_{2} \mathrm{CH}_{2} \mathrm{CH}_{3}$ ), 1.65-1.85 (m, 2H, $\left.\mathrm{NCH}_{2} \mathrm{CH}_{2} \mathrm{CH}_{3}\right), 4.02$ (t, $2 \mathrm{H}, J=7.5 \mathrm{~Hz}$, $\mathrm{NCH}_{2} \mathrm{CH}_{2} \mathrm{CH}_{3}$ ), 7.18 (d, $\left.1 \mathrm{H}, J=3.3 \mathrm{~Hz}, 5-\mathrm{H}\right), 7.29-7.33$ (m, 1H, 4'-H), 7.34 (d, 1H, $J=3.3 \mathrm{~Hz}, 4-\mathrm{H}), 7.41$ (dd, $1 \mathrm{H}, J=3.4$ and $1.2 \mathrm{~Hz}, 3$ '-H), 7.92 (dd, $1 \mathrm{H}, J=5.1$ and $1.2 \mathrm{~Hz}$, 5 '-H). ${ }^{13} \mathrm{C} \mathrm{NMR}\left(\mathrm{CDCl}_{3}\right) \delta 11.01,24.23,49.52,109.56,111.92,112.60,112.92$, 117.14, 125.17, 126.80, 128.03, 130.91, 133.26, 134.40, 134.78. MS (EI) $\mathrm{m} / z$ (\%): 292 $\left(\mathrm{M}^{+}, 100\right), 263$ (30), 236 (47), 224 (48), 196 (11), 170 (8), 147 (7), 109 (5), 86 (4). HRMS: $m / z$ (EI) for $\mathrm{C}_{16} \mathrm{H}_{12} \mathrm{~N}_{4} \mathrm{~S}$; calcd 292.0783; found: 292.0788. Anal. Calcd for $\mathrm{C}_{16} \mathrm{H}_{12} \mathrm{~N}_{4} \mathrm{~S}: \mathrm{C}, 65.74 ; \mathrm{H}, 4.11 ; \mathrm{N}, 19.17$;, 10.97 . Found: C, 65.77; H, 4.33; N, 18.83; S, 11.13 .

1-Phenyl-2-(2'-thienyl)-5-tricyanovinylpyrrole 1b. Gold-like lustrous crystals (35\%). Mp: 184.8-185.7 ㄷ. UV (EtOH): $\lambda_{\max } \mathrm{nm}\left(\varepsilon / \mathrm{M}^{-1} \mathrm{~cm}^{-1}\right) 511.5$ (19086), 376.0 (11580), 
271.5 (9690). IR (Nujol) v 2211 (CN), 1505, 1403, 1321, 1240, 1229, 1198, 1091, 987, 896, 848, 782, 774, 716, $697 \mathrm{~cm}^{-1} .{ }^{1} \mathrm{H}$ NMR (Acetone-d 6 ) $\delta$ 7.08-7.10 (m, 1H, 4'-H), $7.18(\mathrm{~d}, 1 \mathrm{H}, J=4.5 \mathrm{~Hz}, 3-\mathrm{H}), 7.30$ (dd, $1 \mathrm{H}, J=3.9$ and $\left.1.2 \mathrm{~Hz}, 3^{\prime}-\mathrm{H}\right), 7.60$ (dd, $1 \mathrm{H}, J=5.1$ and $1.2 \mathrm{~Hz}, 5$ '-H), 7.66-7.69 (m, 5H, 5xAr-H), $7.92(\mathrm{~d}, 1 \mathrm{H}, J=4.5 \mathrm{~Hz}, 4-\mathrm{H}) .{ }^{13} \mathrm{C} \mathrm{NMR}$ $\left(\mathrm{CDCl}_{3}\right) \delta 110.85,113.12,113.96,114.17,123.64,125.98,127.66,127.80,129.06$, 129.34, 130.12, 130.24, 131.08, 131.92, 134.67, 142.03. MS (EI) m/z (\%): $326\left(\mathrm{M}^{+}\right.$, 100), 300 (5), 100 (8). HRMS: $m / z$ (EI) for $\mathrm{C}_{19} \mathrm{H}_{10} \mathrm{~N}_{4} \mathrm{~S}$; calcd 326.0626; found: 326.0626 .

1-Naphthyl-2-(2'-thienyl)-5-tricyanovinylpyrrole 1c. Gold-like lustrous crystals (34\%). Mp: 175.1-176.2 ${ }^{\circ} \mathrm{C}$. UV (EtOH): $\lambda_{\max } \mathrm{nm}\left(\varepsilon / \mathrm{M}^{-1} \mathrm{~cm}^{-1}\right) 516.5$ (32160), 286.0 (10753). IR (Nujol) v 2207 (CN), 1594, 1505, 1463,1376, 1318, 1261, 1205, 1169, 1112, 954, 895, 848, 809, 776, 743, 709, $612 \mathrm{~cm}^{-1}$. 1'H NMR (Acetone-d 6 ) $\delta$ 6.97-7.02 (m, 1H, 4'$\mathrm{H}), 7.20(\mathrm{~m}, 1 \mathrm{H}, \operatorname{Ar}-H), 7.35(\mathrm{dd}, 1 \mathrm{H}, J=3.9$ and $1.2 \mathrm{~Hz}, 3$ '-H), 7.40 (d, $1 \mathrm{H}, J=4.8 \mathrm{~Hz}$, 3-H), 7.45 (dd, $1 \mathrm{H}, J=5.1$ and $\left.1.2 \mathrm{~Hz}, 5^{\prime}-\mathrm{H}\right), 7.60-7.70$ (m, 2H, 2xAr-H), 7.76-7.82 (m, $1 \mathrm{H}, \operatorname{Ar}-H$ ), 7.98 (dd, $1 \mathrm{H}, J=7.7$ and $1.2 \mathrm{~Hz}, \mathrm{Ar}-H$ ), 8.14 (d, 1H, J=4.8 Hz, 4-H), 8.17$8.20(\mathrm{~m}, 1 \mathrm{H}, \mathrm{Ar}-H), 8.38$ (br d, $1 \mathrm{H}, J=8.4 \mathrm{~Hz}, \mathrm{Ar}-H) .{ }^{13} \mathrm{C} \mathrm{NMR}\left(\mathrm{CDCl}_{3}\right) \delta 110.90$, $113.09,114.13,114.15,121.05,123.80,125.35,125.55,127.56,127.61,128.07$, $128.88,128.95,129.13,129.46,129.50,130.76,130.85,132.06,132.72,134.26$, 142.68. MS (EI) $m / z(\%): 376\left(\mathrm{M}^{+}, 100\right), 375$ (12), 346 (4), 311 (11), 273 (2), 241 (2), 136 (4), 127 (6), 126 (3), 69 (5). HRMS: $m / z$ (EI) for $\mathrm{C}_{23} \mathrm{H}_{12} \mathrm{~N}_{4} \mathrm{~S}$; calcd 376.0783; found: 326.0781 .

1-(4"'-Methoxyphenyl)-2-(2'-thienyl)-5-tricyanovinylpyrrole 1d. Dark red solid with metallic luster (50\%). Mp: 156.9-157.2 ${ }^{\circ} \mathrm{C}$. UV (EtOH): $\lambda \max n m\left(\varepsilon / \mathrm{M}^{-1} \mathrm{~cm}^{-1}\right) 519.0$ (31639), 339.5 (4716), 297.5 (7226), 281.5 (7154), 232.5 (19,927). IR (Nujol) $v 2212$ (CN), 1506, 1465, 1432, 1404, 1381, 1322, 1254, 1201, 1020, $987 \mathrm{~cm}^{-1}$. ${ }^{1} \mathrm{H}$ NMR (Acetone- $\mathrm{d}_{6}$ ) $\delta 3.97\left(\mathrm{~s}, 3 \mathrm{H}, \mathrm{OCH}_{3}\right), 7.09-7.13\left(\mathrm{~m}, 1 \mathrm{H}, 4^{\prime}-\mathrm{H}\right), 7.17-7.23(\mathrm{~m}, 3 \mathrm{H}, 3-\mathrm{H}$ and 2xAr- $H$ ), 7.43 (dd, $1 \mathrm{H}, J=3.9$ and $\left.1.2 \mathrm{~Hz}, 3^{\prime}-\mathrm{H}\right), 7.56$ (d, 2H, $\left.J=9.2 \mathrm{~Hz}, 2 \mathrm{xAr}-H\right), 7.61$ (dd, $1 \mathrm{H}, J=5.1$ and $1.2 \mathrm{~Hz}, 5$ '-H), $7.92(\mathrm{~d}, 1 \mathrm{H}, J=4.8 \mathrm{~Hz}, 4-\mathrm{H}) .{ }^{13} \mathrm{C}$ NMR $\left(\mathrm{CDCl}_{3}\right) \delta$ 55.70, 111.06, 113.29, 113.96, 114.12, 115.30, 123.54, 125.83, 126.77, 127.74, 128.18, 129.14, 129.47, 131.16, 131.32, 142.36, 162.19. Anal. Calcd for $\mathrm{C}_{20} \mathrm{H}_{12} \mathrm{~N}_{4} \mathrm{OS}: \mathrm{C}$, 67.35; H, 3.40; N, 15.73; S, 9.00. Found: C, 67.03; H, 3.69; N, 15.40; S, 8.93. 
1-(2",4"'-Dimethoxyphenyl)-2-(2'-thienyl)-5-tricyanovinylpyrrole 1e. Red-violet solid with metallic luster (63\%). Mp: 182.8-183.8 ${ }^{\circ} \mathrm{C}$. UV (EtOH): $\lambda \max \mathrm{nm}\left(\varepsilon / \mathrm{M}^{-1} \mathrm{~cm}^{-1}\right)$ 525.5 (36407), 335.0 (4502), 292.0 sh. (7730), 283.5 (9088), 232.5 (17173). IR (Nujol) v $2210(\mathrm{CN}), 1616,1588,1505,1465,1434,1403,1381,1314,1294,1259,1230$, 1212, 1200, 1161, 1135, 1096, 1027, 986, 942, 850, 803, $787 \mathrm{~cm}^{-1}$. 1'H NMR (Acetoned 6 ) $\delta 3.83\left(\mathrm{~s}, 3 \mathrm{H}, \mathrm{OCH}_{3}\right), 3.97\left(\mathrm{~s}, 3 \mathrm{H}, \mathrm{OCH}_{3}\right), 6.77(\mathrm{dd}, 1 \mathrm{H}, J=8.7$ and $2.7 \mathrm{~Hz}, 5$ ' $-\mathrm{H})$, $6.86(\mathrm{~d}, 1 \mathrm{H}, J=2.7 \mathrm{~Hz}, 3$ ' '-H), 7.11-7.14 (m, 1H, 4'-H), 7.24 (d, 1H, J=4.8 Hz, 3-H), 7.39 (d, 1H, J=8.7 Hz, 6' '-H), 7.53 (dd, 1H, J=3.9 and $1.2 \mathrm{~Hz}, 3$ '-H), 7.61 (dd, 1H, $J=5.2$ and $\left.1.2 \mathrm{~Hz}, 5{ }^{\prime}-\mathrm{H}\right), 7.95(\mathrm{~d}, 1 \mathrm{H}, J=4.8 \mathrm{~Hz}, 4-\mathrm{H}) .{ }^{13} \mathrm{C} \mathrm{NMR}\left(\mathrm{CDCl}_{3}\right) \delta 55.76$, 55.93, 99.95, 105.46, 111.19, 113.63, 114.03, 114.47, 115.60, 123.79, 125.25, 127.65, $128.08,129.06,129.57,131.19,131.95,142.69,158.35,164.04$. Anal. Calcd for $\mathrm{C}_{21} \mathrm{H}_{14} \mathrm{~N}_{4} \mathrm{O}_{2} \mathrm{~S}$ : C, 65.27; H, 3.63; N, 14.50; S, 8.30. Found: C, 65.27; H, 3.86; N, $14.03 ; \mathrm{S}, 8.38$.

1-(3',5"-Dimethoxyphenyl)-2-(2'-thienyl)-5-tricyanovinylpyrrole 1f. Bronze-like lustrous crystals (37\%). Mp: 149.3-150.3 ${ }^{\circ} \mathrm{C}$. UV (EtOH): $\lambda \max n$ m $\left(\varepsilon / \mathrm{M}^{-1} \mathrm{~cm}^{-1}\right) 514.5$ (24604), 341.5 (4413), 286.0 (8144), 222.0 sh. (1851). IR (Nujol) v 2216 (CN), 1607, 1512, 1466, 1429, 1407, 1292, 1238, 1209, 1176, 1157, 1005, 850, 768, $718 \mathrm{~cm}^{-1} .{ }^{1} \mathrm{H}$

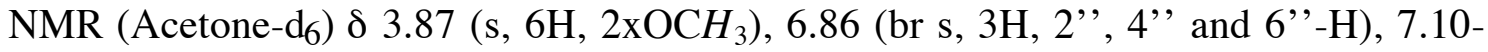
7.14 (m, 1H, 4'-H), 7.17 (d, 1H, J=4.8 Hz, 3-H), 7.40 (dd, 1H, J=2.7 and 1.2 Hz, 3'-H), $7.63(\mathrm{dd}, 1 \mathrm{H}, J=5.2$ and $1.2 \mathrm{~Hz}, 5$ '-H), 7.89 (d, $1 \mathrm{H}, J=4.8 \mathrm{~Hz}, 4-\mathrm{H}) .{ }^{13} \mathrm{C} \mathrm{NMR}\left(\mathrm{CDCl}_{3}\right)$ $\delta$ 55.82, 103.39, 108.72, 110.93, 113.21, 113.98, 114.03, 123.53, 126.03, 127.32, 127.81, 129.07, 129.48, 130.95, 135.77, 141.74, 161.70. MS (EI) m/z (\%): $386\left(\mathrm{M}^{+}\right.$, 100), 360 (8), 149 (7), 98 (8). HRMS: (EI) $m / z$ (\%) for $\mathrm{C}_{21} \mathrm{H}_{14} \mathrm{~N}_{4} \mathrm{O}_{2} \mathrm{~S}$; calcd 386.0837; found 386.0847 .

1-(3",4",5"-Trimethoxyphenyl)-2-(2'-thienyl)-5-tricyanovinylpyrrole 1g. Bronze-like lustrous crystals (73\%). Mp: 206.8-207.6 ${ }^{\circ} \mathrm{C}$. UV (EtOH): $\lambda_{\max } \mathrm{nm}\left(\varepsilon / \mathrm{M}^{-1} \mathrm{~cm}^{-1}\right) 519.0$ (30842), 339.5 (4855), 283.0 (7558), $235.0 \mathrm{sh}$ (1493), 209.0 (48174). IR (liquid film) $v$ 2207 (CN), 1593, 1503, 1426, 1402, 1383, 1297, 1227, 1185, 1166, 1126, 1080, 851, 830, 776, 673, $504 \mathrm{~cm}^{-1} .{ }^{1} \mathrm{H}$ NMR (Acetone-d 6$) \delta 3.87\left(\mathrm{~s}, 9 \mathrm{H}, 3 \mathrm{xOCH}_{3}\right), 7.04(\mathrm{~s}, 2 \mathrm{H}$, 2' 'and 6' '-H), 7.11-7.15 (m, 1H, 4'-H), 7.21 (d, 1H, J=5.1 Hz, 3-H), 7.48 (dd, 1H, 
$J=3.0$ and $\left.1.2 \mathrm{~Hz}, 3^{\prime}-\mathrm{H}\right), 7.64\left(\mathrm{dd}, 1 \mathrm{H}, J=4.8\right.$ and $\left.1.2 \mathrm{~Hz}, 5^{\prime}-\mathrm{H}\right), 7.92$ (d, 1H, J=5.1 Hz, 4-H). ${ }^{13} \mathrm{C} \mathrm{NMR}\left(\mathrm{CDCl}_{3}\right) \delta 56.56,61.49,107.93,111.15,113.31,113.85,114.13$, 123.59 , 125.73, 127.79, 127.84, 129.19, 129.42, 129.70, 130.91, 141.43, 142.06, 154.24. MS (EI) $m / z(\%): 416\left(\mathrm{M}^{+}, 100\right), 401$ (9), 361 (5). HRMS: $m / z$ (EI) for $\mathrm{C}_{22} \mathrm{H}_{16} \mathrm{~N}_{4} \mathrm{O}_{3} \mathrm{~S}$; calcd 416.0943; found: 416.0991.

1-(4',-Fluorophenyl)-2-(2'-thienyl)-5-tricyanovinylpyrrole $\mathbf{1 h}$. Gold-like lustrous crystals (37\%). Mp: $187-188{ }^{\circ} \mathrm{C}$. UV (EtOH): $\lambda_{\max } \mathrm{nm}\left(\varepsilon / \mathrm{M}^{-1} \mathrm{~cm}^{-1}\right) 510.5$ (30176), 333.0 (4248), 296.0 (6311), 228.8 (9076). IR (Nujol) v 2204 (CN), 1503, 1466, 1433, 1403, 1380, 1320, 1194, 1090, 989, 851, 816, $775 \mathrm{~cm}^{-1} .{ }^{1} \mathrm{H}$ NMR (Acetone-d 6 ) $\delta$ 7.107.14 (m, 1H, 4'-H), 7.20 (d, 1H, J=4.8 Hz, 3-H), 7.38 (dd, 1H, J=3.9 and 1.2 Hz, 3'-H), 7.47 (t, 2H, $J=8.7 \mathrm{~Hz}, 2 \mathrm{xAr}-H), 7.63$ (dd, $1 \mathrm{H}, J=5.2$ and $1.2 \mathrm{~Hz}, 5$ '-H), 7.77 (dd, 2H, $J$ $=9.3$ and $4.8 \mathrm{~Hz}, 2 \mathrm{xAr}-H), 7.94(\mathrm{~d}, 1 \mathrm{H}, J=4.8 \mathrm{~Hz}, 4-\mathrm{H}) .{ }^{13} \mathrm{C}$ NMR (Acetone- $\left.\mathrm{d}_{6}\right) \delta$ 110.58, 112.18, 114.44, 114.91, 115.00, 117.86 (d, J=23.2 Hz, C3', C5'), 124.18, 126.83, 128.64, 128.84, 130.68, 130.69, 131.90, 133.87 (d, J=9.5 Hz, C2', C6' '), 142.83, 165.35 (d, J=249.8 Hz, C4'’). MS (EI) m/z (\%): $344\left(\mathrm{M}^{+}, 100\right), 318$ (5), 242 (5), 208 (3), 169 (3), 145 (3), 95 (4), 84 (4), 69 (11). HRMS: m/z (EI) for $\mathrm{C}_{19} \mathrm{H}_{9} \mathrm{FN} 4 \mathrm{~S}$; calcd 344.0532; found: 344.0530 .

1-(4"'-Bromophenyl)-2-(2'-thienyl)-5-tricyanovinylpyrrole 1i. Red-pink with metallic luster (31\%). Mp: 175.1-175.4 ${ }^{\circ} \mathrm{C}$. UV (EtOH): $\lambda_{\max } \mathrm{nm}\left(\varepsilon / \mathrm{M}^{-1} \mathrm{~cm}^{-1}\right) 509.0$ (30457), 332.0 (4986), 293.0 (7093), 230.0 (19,779). IR (Nujol) v 2213 (CN), 1505, 1427, 1401, $1322,1231,1200,1067,1014,986,846,830,786,746,724,683,634 \mathrm{~cm}^{-1} .{ }^{1} \mathrm{H}$ NMR (Acetone-d $\left.{ }_{6}\right) \delta 7.10-7.14(\mathrm{~m}, 1 \mathrm{H}, 4$ '-H), $7.18(\mathrm{~d}, 1 \mathrm{H}, J=4.8 \mathrm{~Hz}, 3-\mathrm{H}), 7.36(\mathrm{dd}, 1 \mathrm{H}$, $J=3.8$ and $\left.1.2 \mathrm{~Hz}, 3^{\prime}-\mathrm{H}\right), 7.64$ (dd, $1 \mathrm{H}, J=5.1$ and $\left.1.2 \mathrm{~Hz}, 5^{\prime}-\mathrm{H}\right), 7.67$ (d, 2H, $J=8.7 \mathrm{~Hz}$, 2xAr-H), 7.89 (d, 2H, J= 8.7 Hz, 2xAr- $H$ ), 7.92 (d, 1H, J=4.8 Hz, 4-H). MS (EI) $m / z$ (\%): $406\left(\mathrm{M}^{+}{ }^{81} \mathrm{Br}, 100\right), 404\left(\mathrm{M}^{+} 79 \mathrm{Br}, 97\right), 403$ (7), 325 (9), 297 (6), 249 (5), 216 (5), 196 (3), 163 (4), 149 (8), 136 (6), 76 (5). HRMS: $m / z$ (EI) for $\mathrm{C}_{19} \mathrm{H}_{9}{ }^{81} \mathrm{BrN}_{4} \mathrm{~S}$; calcd 405.9711; found: 405.9726, Anal. Calcd for $\mathrm{C}_{19} \mathrm{H}_{9} \mathrm{BrN}_{4} \mathrm{~S}$ : C, 56.29; H, 2.22; N, 13.83; S, 7.92. Found: C, 56.12; H, 2.69; N, 13.22; S, 7.97.

\section{Acknowledgements}


Thanks are due to Foundation for Science and Technology (Portugal) for financial support through IBQF (UM) and through POCTI, FEDER (ref. POCTI/QUI/37816/2001).

\section{References}

1. Zyss, D. S. In: Non linear optical properties of organic molecules and crystals; Academic Press: Orlando, 1987, Vols. 1 and 2.

2. Prasad, P. N.; Williams, D. J. Introduction to Nonlinear Optical Effects in Molecules and Polymers; Wiley: New York, 1991, pp. 132-174.

3. Drost, K. J.; Jen, A. K.-I.; Rao, V. P. Chemtech 1995, 25(9), 16 and references cited therein.

4. Rao, V. P.; Jen, A. K.-I.; Wong, K. I.; Drost, K. J. Tetrahedron Lett. 1993, 34(11), 1747.

5. Mignani, G.; Leising, F.; Meyrueix, R.; Samson, M. Tetrahedron Lett. 1990, $31(33), 4743$.

6. Effenberger, F.; Wurthner, F. Angew. Chem. 1993, 105, 742.

7. Effenberger, F.; Wurthner, F. Angew. Chem. Int. Ed. Eng. 1993, 32, 719.

8. Effenberger, F.; Wurthner, F.; Steybe F. J. Org. Chem. 1995, 60, 2082.

9. Hutchins, M. G.; Ferguson, I.; McGeein, D. J.; Morley, J. O.; Ziss, J.; Ledoux, I. J. Chem. Soc. Perkin Trans 2 1995, 171, 176.

10. Bedworth, P. V.; Cai, Y.; Jen, A.; Marder, S. R. J. Org. Chem 1996, 61, 2242.

11. Steybe, F.; Effenberger, F; Beckman, S.; Kramer, P.; Glania, C.; Wortmann, R. Chem. Phys. 1997, 219, 317.

12. Steybe, F.; Effenberger, F; Gubler, U.; Bosshard, C.; Gunter, P. Tetrahedron 1998, 54,8469 .

13. Raposo, M. M. M.; Kirsch, G. Tetrahedron 2003, 59(26), 4891.

14. Raposo, M. M. M.; Fonseca, A. M. C.; Kirsch, G. Tetrahedron 2004, 60(18), 4071.

15. Raposo, M. M. M.; Fonseca, A. M. C.; Kirsch, G. Mater. Sci. Forum 2004, 455456, 157.

16. Batista, R. M. F.; Costa, S. P. G.; Raposo, M. M. M. Tetrahedron Lett. 2004, 45(13), 2825.

17. Lucchesini, F. Tetrahedron 1992, 48, 9951. 
18. Roncali, J. Chem. Rev. 1992, 92, 711.

19. Roncali, J. Chem. Rev. 1997, 97, 173.

20. Ogura, K.; Yanay, H.; Miokawa, M.; Akazome, M. Tetrahedron Lett. 1999, 40(50), 8887.

21.Zhao, R.; Akazome M.; Matsumoto, S.; Ogura, K. Tetrahedron 2002, 58(51), 10225 and references cited therein.

22.Zhao, R.; Akazome, M.; Matsumoto, S.; Ogura, K. Bull. Chem. Soc. Jpn. 2002, 75(8), 2359.

23.Zhao, R.; Matsumoto, S.; Akazome, M.; Ogura, K. Tetrahedron 2002, 58(51), 10233.

24.Ogura, K.; Zhao, R.; Jiang, M.; Akazome, M.; Matsumoto, S.; Yamaguchi, K. Tetrahedron Lett. 2003, 44(18), 3595.

25. Just, P. E.; Chane-Ching, K. I.; Lacaze, P. C. Tetrahedron 2002, 58(18), 3467.

26. Kotkar, D.; Joshi, V.; Ghosh, P. K. J. Chem. Soc. Chem. Commun. 1988, 917.

27. Parakka, J. P.; Cava, M.P. Synth. Met. 1995, 68, 275.

28. McCullough, R. D.; Lowe, R. D.; Jayaraman, M.; Anderson, D. J. Org. Chem. 1993, 58, 904.

29. Ono, K.; Totani, H.; Ohkita, M.; Saito, K.; Kato, M. Heterocycles 2004, 64(1), 223.

30.Eckert, K.; Schroder, A.; Hartmann, H. Eur. J. Org. Chem. 2000, 1327 and references cited therein.

31. Raposo, M. M. M.; Kirsch G. Heterocycles 2001, 55(8), 1487.

32.Costa, F., Silva; C. J. R.; Raposo, M. M. M.; Fonseca, A. M.; Neves, I. C.; Carvalho, A. P.; Pires, J. Microporous Mesoporous Mater. 2004, 72, 111.

33. Raposo, M. M. M.; Sampaio, A. M. B. A.; Kirsch, G. Synthesis, 2005, 2, 199.

34. Jackson, A. H., Pyrroles In The Chemistry of Heterocyclic Compounds; Vol. 48, Part 1; Jones, R. A., Ed.; Wiley: New York, 1990, 295 and references cited therein.

35. Belen'kii, L. I. Kim. Geterotsikl. Soed. 1980, 12, 1587.

36. Belen'kii, L. I. Heterocycles 1994, 37(3), 2029.

37. Boukou-Poba, J.-P.; Farnier, M.; Guilard, R. Tetrahedron Lett. 1979, $20(19), 1717$.

38. Boukou-Poba, J.-P.; Farnier, M.; Guilard, R. Can. J. Chem. 1981, 59, 2962.

39. Trofimov, B. A.; Korostova, S. E.; Mikhaleva, A. I.; Nesterenko, R.N.; Sigalov, M. V.; Voronov, V. K.; Polovnikova, R. I. Zh. Org. Kim. 1982, 18, 894. 
40. Korostova, S. E.; Nesterenko, R. N.; Mikhaleva, A. I.; Shevchenko, S. G.; Kalabin, G. A.; Polovnikova, R. I. Kim Geterotsikl. Soedin. 1990, 273.

41. Korostova, S. E.; Nesterenko, R. N.; Mikhaleva, A. I.; Shevchenko, S. G.; Kalabin, G. A.; Polovnikova, R. I. Kim. Geterotsikl. Soed. 1991, 337.

42.Korostova, S. E.; Mikhaleva, A. I.; Trofimov, B. A. Russ. Chem. Rev. (Engl. Transl.) 1999, 68(6), 459.

43. Trofimov, B. A.; Sobenina, L. N.; Demenev, A. P.; Mikhaleva, A. I.; Ushakov, I. A.; Tarasova, O. A.; Smirnov, V. I.; Petrushenko, K. B.; Vokin, A. I.; Murzina, N. M.; Myachina, G. F. Arkivok 2001, ix, 37.

44.Raposo, M. M. M.; Sousa, A. M. R. C.; Fonseca, A. M. C.; Kirsch, G. "Thienylpyrrole azo dyes: synthesis, solvatochromic and electrochemical properties" accepted for publication in Tetrahedron.

45. Casado, J.; Pappenfus, T. M.; Miller, L. L.; Mann, K. R.; Orti, E.; Viruela, P. M.; Pou-Amerigo, R.; Hernandez, V.; Navarrete, J. T. L. J. Am. Chem. Soc. 2003, 125, 2524.

46. Rao, V. P.; Jen, A. K.-Y.; Wang, K. Y.; Drost, K. J. J. Chem. Soc. Chem. Commun. $1993,1118$.

47. Gilat, S. L.; Kawai, S. H.; Lehn, J.-M. J. Chem. Soc. Chem. Commun. 1993, 1439.

48. Gilat, S. L.; Kawai, S. H.; Lehn, J.-M. Chem. Eur. J. 1995, 1, 275.

49. Kamlet, M. J.; Abboud, J-L. M.; Abraham, M. H.; Taft, R. W. J. Org. Chem. 1983, $48,2877$.

50. Kamlet, M. J.; Abboud, J-L M.; Abraham, M. H.; Taft, R. W. J. Am. Chem. Soc. 1977, 99, 6027.

51. McCormac, T.; Farrell, D. Electrochimica Acta 2001, 46, 3287.

52. Pei, J.; Ni, J.; Zhou, X. H.; Cao, X. Y.; Lai, Y. H. J. Org. Chem. 2002, 67, 8104.

53. Clays, K.; Persoons, A. Rev. Sci. Instrum. 1992, 63, 3285.

54. Clays, K.; Persoons, A. Phys. Rev. Lett. 1991, 66, 2980.

55. Oudar, J. L. J. Chem. Phys. 1977, 67, 446.

56. Oudar J. L.; Chemla, D. S. J. Chem. Phys. 1977, 66, 2664.

57. Zyss, J.; Oudar, J. L. Phys. Rev. A 1982, 26, 2016.

58. Teng, C. C.; Garito, A. F. Phys. Rev. B 1983, 28, 6766.

59. Stahelin, M.; Burland, D. M.; Rice, J. E. Chem. Phys. Lett., 1992, 191, 245. 


\section{Captions}

Scheme 1. Synthesis of tricyanovinyl-thienylpyrroles $\mathbf{1 a - i}$ from thienylpyrroles $\mathbf{2 a - i}$ by tricyanovinylation reaction with TCNE.

Table 1. Yields, IR and UV-vis data of trycianovinyl-thienylpyrroles $\mathbf{1}$ and thienylpyrroles 2.

*All the UV/vis spectra were run in ethanol.

Table 2. Solvatochromic data $\left[\lambda_{\max }(\mathrm{nm})\right.$ and $\bar{v}_{\max }\left(\mathrm{cm}^{-1}\right)$ of the charge-transfer band $]$ for trycianovinyl-thienylpyrroles $\mathbf{1} \mathbf{a}_{1}, \mathbf{1} \mathbf{a}_{2}$ and $\mathbf{1 g}$ in selected solvents with $\pi^{*}$ values by Kamlet and Taft. 49

a Solvent used as received.

$\mathrm{b}$ The correlation coefficient $r$ obtained for the linear solvatation energy relationship with $\pi^{*}$ values by Kamlet and Taft for aliphatic and dipolar aprotic solvents was $r=$ $0.9830\left(\mathbf{1 a}_{\mathbf{1}}\right), 0.9658\left(\mathbf{1 a}_{\mathbf{2}}\right)$ and 0.9419 for $(\mathbf{1 g})$.

Table 3. Cyclic voltammetry data for thienylpyrroles 2 and 5-tricyanovinyl-substituted thienylpyrroles 1 at a glassy carbon electrode.

a Solution approximately $1-2 \mathrm{mM}$ in each compounds in acetonitrile $0.10 \mathrm{M}$ $\left[\mathrm{NBu}_{4}\right]\left[\mathrm{BF}_{4}\right]$ was used, and the scan rate was $100 \mathrm{mV} \mathrm{s}$, potentials versus the ferrocinium-ferrocene-couple.

${ }^{\mathrm{b}} E_{\text {HOMO }}=4.39+\mathrm{E}_{\mathrm{ox}}(\mathrm{eV})$ and $E_{L U M O}=\mathrm{E}_{\mathrm{red}}+4.39(\mathrm{eV})$

Table 4. UV-visible absorptions, $\beta$ values, $\beta_{0}$ values for PNA and for compounds 1 . $^{\mathrm{a}}$

a Experimental hiperpolarizabilities and spectroscopic data measured in dioxane solutions.

b All the compounds are transparent at the $1064 \mathrm{~nm}$ fundamental wavelength.

c Data corrected for resonance enhancement at $532 \mathrm{~nm}$ using the two-level model with $\beta_{0}=\beta\left[1-\left(\lambda_{\max } / 1064\right)^{2}\right]\left[1-\left(\lambda_{\max } / 532\right)^{2}\right] ;$ damping factors not included $1064 \mathrm{~nm} .{ }^{55-57}$ 
Figure 1. UV-visible spectra of compounds $1 \mathbf{e}$ and $\mathbf{2 e}$ recorded in ethanol.

Figure 2. Cyclic voltammograms of 5-tricyanovinyl-thienylpyrrole 1d, recorded in acetonitrile $-0.1 \mathrm{M}\left[\mathrm{NBu}_{4}\right]\left[\mathrm{BF}_{4}\right]$ at a vitreous carbon electrode (area $=0.049 \mathrm{~cm}^{2}$ ). Scan rate $=200 \mathrm{mV} \mathrm{s}^{-1}$, concentration of compound $=10^{-3} \mathrm{M}$. (a) between $-0.40 \mathrm{~V}$ and 1.18 $\mathrm{V}$ versus ferrocenium-ferrocene; (b) between $-0.40 \mathrm{~V}$ and -2.20 versus ferroceniumferrocene. 
Tables

TABLE 2

\begin{tabular}{|c|c|c|c|c|c|c|c|}
\hline \multirow{2}{*}{$\begin{array}{l}\text { Solvent }^{\mathrm{a}} \\
\text {-hexane }\end{array}$} & \multirow{2}{*}{$\begin{array}{c}\pi^{*^{\mathbf{b}}} \\
-0.08\end{array}$} & \multicolumn{2}{|c|}{$\begin{array}{c}\text { Compound 1a } \\
\lambda_{\max }[\mathrm{nm}] v_{\max }\left[\mathrm{cm}^{-1}\right]\end{array}$} & \multicolumn{2}{|c|}{$\begin{array}{c}\text { Compound 1a } \\
\lambda_{\max }[\mathrm{nm}] v_{\max }\left[\mathrm{cm}^{-1}\right]\end{array}$} & \multicolumn{2}{|c|}{$\begin{array}{c}\text { Compound 1g } \\
\lambda_{\max }[\mathrm{nm}] v_{\max }\left[\mathrm{cm}^{-1}\right]\end{array}$} \\
\hline & & 468.8 & 21,331 & - & - & 502.5 & 19,900 \\
\hline cyclohexane & 0.00 & 470.2 & 21,268 & 395.2 & 25,240 & 506.5 & 19,743 \\
\hline diethyl ether & 0.27 & 480.8 & 20,799 & 404.4 & 24,728 & 513.0 & 19,493 \\
\hline ethyl acetate & 0.55 & 485.4 & 20,602 & 407.6 & 24,534 & 513.0 & 19,493 \\
\hline toluene & 0.54 & 490.2 & 20,400 & 407.4 & 24,546 & 519.5 & 19,249 \\
\hline ethanol & 0.54 & 491.2 & 20,358 & 407.4 & 24,546 & 519.0 & 19,268 \\
\hline THF & 0.58 & 490.2 & 20,400 & 408.2 & 24,498 & 517.0 & 19,342 \\
\hline methanol & 0.60 & 490.2 & 20,400 & 405.6 & 24,655 & 520.0 & 19,231 \\
\hline acetone & 0.71 & 491.0 & 20,367 & 410.4 & 24,366 & 518.0 & 19,305 \\
\hline acetonitrile & 0.75 & 494.0 & 20,243 & 412.2 & 24,260 & 518.5 & 19,286 \\
\hline chloroform & $0.76^{50}$ & 497.8 & 20,088 & 412.8 & 24,225 & 525.5 & 19,029 \\
\hline dichloromethane & 0.82 & 500.6 & 19,976 & 415.8 & 24,050 & 526.0 & 19,011 \\
\hline DMF & 0.88 & 499.0 & 20,049 & 417.0 & 23,980 & 528.0 & 18,939 \\
\hline DMSO & 1.00 & 506.6 & 19,739 & 421.0 & 23,697 & 533.5 & 18,744 \\
\hline
\end{tabular}


Table 3

Thienylpyrroles 2

Tricyanovinyl-substituted thienylpyrroles 1

\begin{tabular}{ccccccc} 
Compound & $\begin{array}{c}\text { Oxidation }^{\mathrm{a}} \\
\mathrm{E}_{\mathrm{pa}}(\mathrm{V})\end{array}$ & Compound $^{\text {Oxidation }}{ }^{\mathrm{a}}$ & \multicolumn{2}{c}{ Reduction $^{\mathrm{a}}$} & band gap $^{\mathrm{b}}$ \\
$\mathbf{2 a}$ & 0.57 & $\mathbf{1 a}$ & 1.11 & 0.92 & 1.61 & 2.03 \\
$\mathbf{2 b}$ & 0.53 & $\mathbf{1 b}$ & 0.95 & 1.00 & 1.70 & 1.95 \\
$\mathbf{2 c}$ & 0.54 & $\mathbf{1 c}$ & 0.96 & 1.02 & 1.73 & 1.98 \\
$\mathbf{2 d}$ & 0.48 & $\mathbf{1 d}$ & 0.94 & 1.14 & 1.80 & 2.08 \\
$\mathbf{2 e}$ & 0.45 & $\mathbf{1 e}$ & 0.92 & 1.05 & 1.75 & 1.97 \\
$\mathbf{2 f}$ & 0.48 & $\mathbf{1 f}$ & 0.95 & 1.01 & 1.78 & 1.96 \\
$\mathbf{2 g}$ & 0.46 & $\mathbf{1 g}$ & 0.94 & 1.06 & 1.72 & 2.00 \\
$\mathbf{2 h}$ & 0.55 & $\mathbf{1 h}$ & 0.97 & 0.94 & 1.78 & 1.91 \\
$\mathbf{2 i}$ & 0.54 & $\mathbf{1 i}$ & 0.98 & 0.99 & 1.70 & 1.97 \\
\hline
\end{tabular}


Table 4

\begin{tabular}{cccc}
\hline Compound & $\boldsymbol{\lambda}$ max $[\mathbf{n m}]$ & $\boldsymbol{\beta}^{\mathbf{b} / 10^{-30}}$ esu & $\boldsymbol{\beta}_{0} \mathbf{c} / 10^{-30} \mathrm{esu}$ \\
\hline $\mathbf{1 a}_{\mathbf{1}}$ & 486 & 254 & 30 \\
$\mathbf{1 a}_{\mathbf{2}}$ & 408 & 317 & 105 \\
$\mathbf{1 a}_{\mathbf{3}}$ & 414 & 240 & 80 \\
$\mathbf{1 b}$ & 504 & 244 & 19 \\
$\mathbf{1 c}$ & 506 & 234 & 17 \\
$\mathbf{1 d}$ & 510 & 253 & 17 \\
$\mathbf{1 e}$ & 514 & 263 & 13 \\
$\mathbf{1 f}$ & 508 & 221 & 15 \\
$\mathbf{1 g}$ & 512 & 225 & 13 \\
$\mathbf{1 h}$ & 506 & 290 & 21 \\
$\mathbf{1 i}$ & 504 & 280 & 22 \\
$\mathbf{P N A}$ & 352 & $16.958-59$ & 8 \\
\hline & & & \\
\hline
\end{tabular}




\section{Schemes}

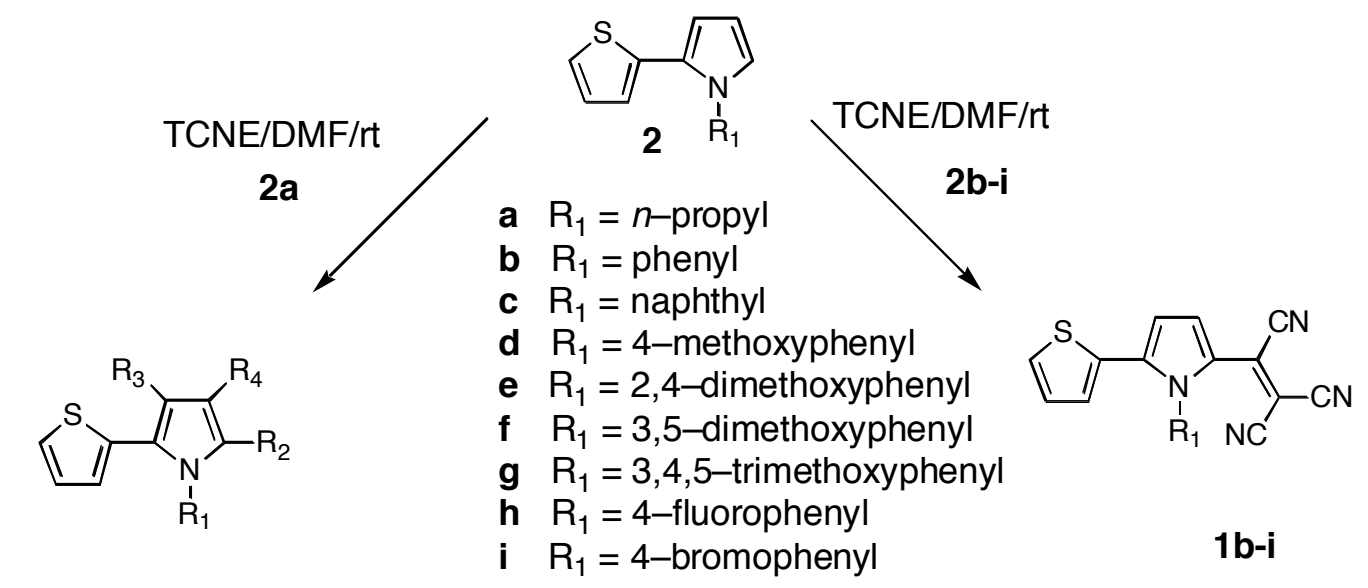

$1 a_{1} \quad R_{2}=C(C N)=C(C N)_{2}, R_{3}=R_{4}=H$

$1 a_{2} \quad R_{3}=C(C N)=C(C N)_{2}, R_{2}=R_{4}=H$

$\mathbf{1 a}_{3} \quad \mathrm{R}_{4}=\mathrm{C}(\mathrm{CN})=\mathrm{C}(\mathrm{CN})_{2}, \mathrm{R}_{2}=\mathrm{R}_{3}=\mathrm{H}$

Scheme 1 
Figures

Figure 1

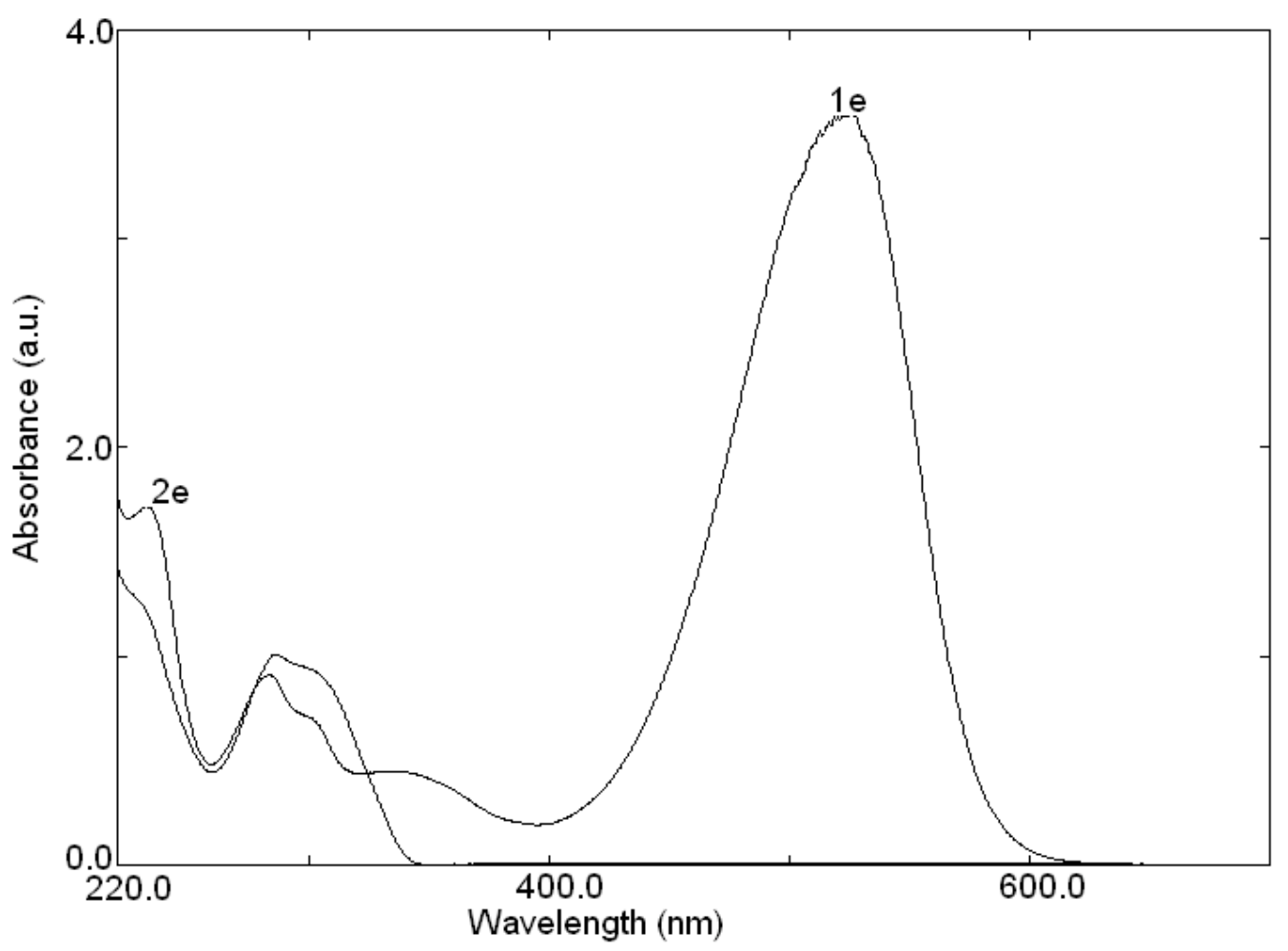


Figure 2
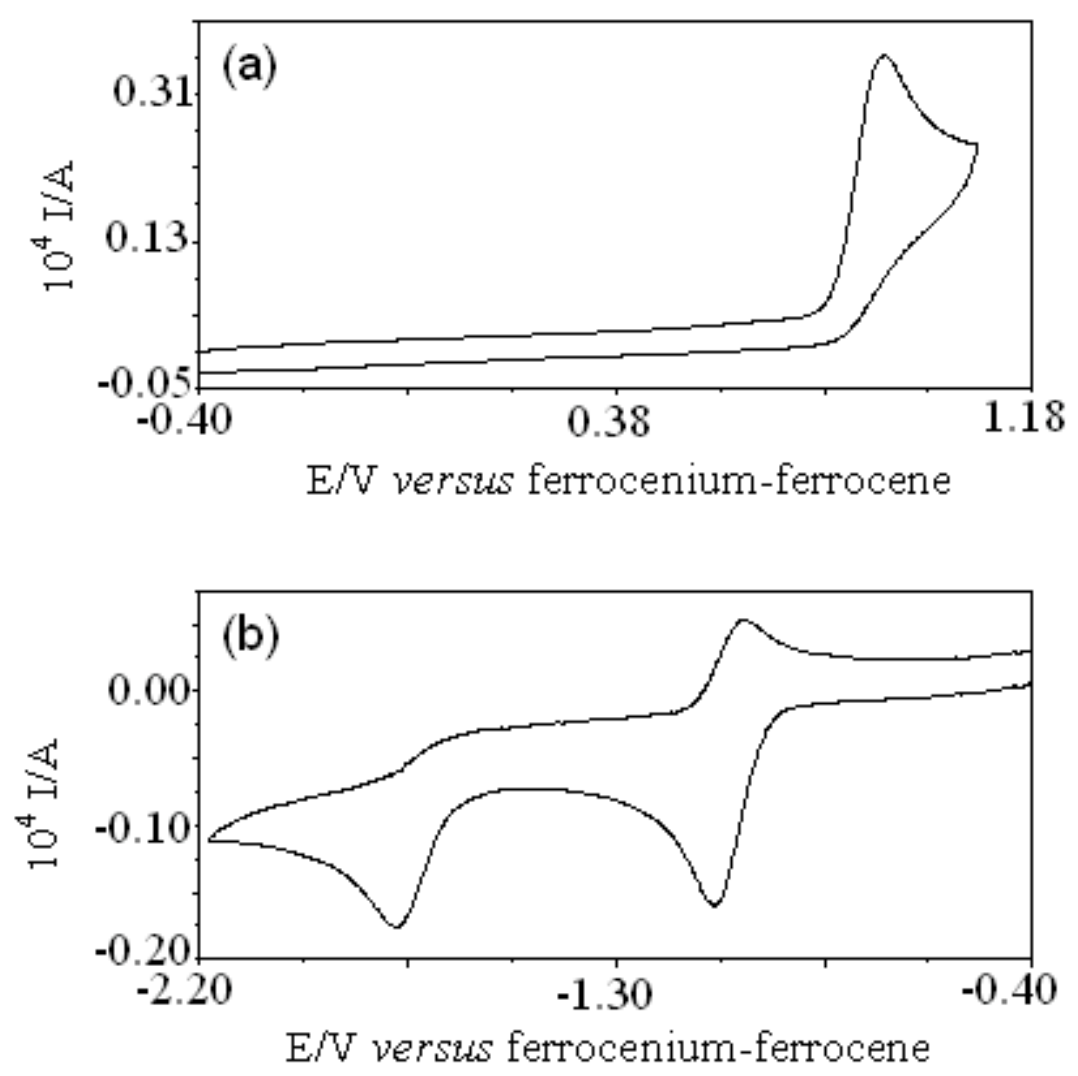